\title{
Psychometric properties and cultural adaptation of Polish version of Gynecological Cancers Awareness Scale (GCAS)
}

\author{
Malgorzata Nagorska ${ }^{1}\left(\mathbb{D}\right.$, Nursel Alp Dal2 ${ }^{2}$, Serap Ejder Apay ${ }^{3}$ (D), \\ Malgorzata Lesinska-Sawicka ${ }^{4}\left({ }^{\circ}\right.$, Canturk Capik $^{5}(0)$ \\ ${ }^{1}$ Institute of Medical Sciences, Medical College of Rzeszow University, Rzeszow, Poland \\ ${ }^{2}$ Midwifery Department, Munzur University, Tunceli, Turkey \\ ${ }^{3}$ Ataturk University Health Science Faculty Midwifery Department, Erzurum, Turkey \\ ${ }^{4}$ Department of Nursing Stanislaw Staszic State University of Applied Science in Pila, Poland \\ ${ }^{5}$ Public Health Nursing Department, Faculty of Nursing, Ataturk University, Erzurum, Turkey
}

\begin{abstract}
Objectives: Cancer of the female genital organs is one of the most common causes of death of women in Poland. The aim of the study was to translate and analyze the psychometric properties of the Polish version of the Gynecological Cancers Awareness Scale (GCAS).

Material and methods: Cross-sectional study and questionnaire technic were used to collect data. The study was conducted from June $10^{\text {th }}$ to July $10^{\text {th }} 2021$ among 443 adult women in Poland.

Results: The Cronbach Alpha measure was used to assess the internal consistency of the scale. Cronbach's Alpha values greater than 0.7 indicates that the scale has high reliability.

Conclusions: The analysis confirms that the Polish version of Gynecological Cancers Awareness Scale has a very high reliability to assess the women's cancers awareness and knowledge of cancers.
\end{abstract}

Key words: gynecological cancers; GCAS; women; cancer prevention

Ginekologia Polska 2022; 93, 9: 695-704

\section{INTRODUCTION}

Cancer has been one of the most common causes of death in Poland for many years, and the number of cases of malignant cancer has more than doubled in recent decades [1]. According to statistics, in 2018 there were quite a few numbers of new cases of malignant tumors of the female genital organs. the incidence rate was $14.5 \%$, which is second only to breast cancer (22.5\%). In addition, female genital malignancies caused $13.5 \%$ of cancer deaths in women (ovarian cancer $-6.1 \%$, uterine shaft cancer $-3.9 \%$, cervical cancer $-3.5 \%$ ) [2].

The problem in the early detection of this group of cancers is the lack of characteristic clinical signs at their initial stage and the unsatisfactory participation of wo- men in recommended preventive studies [1]. Prevention allows early detection of the disease, which increases the chances of their faster and more effective treatment. In order to improve the situation, measures should be taken to raise women's awareness of health-promoting behavior, including their participation in screening. Early diagnosis of gynecological cancers with effective and common screening programs is very important in reducing mortality and morbidity rates [3-9].

The analysis will allow for the preparation of a Polish version of a standardized tool for recognizing women's awareness of female genital cancers. Identifying knowledge deficits can be useful in practice in the implementation of educational programs aimed at women. 


\section{Objectives}

The aim of the study was to translate and analyze the psychometric properties of the Polish version of the Gynecological Cancers Awareness Scale (GCAS).

\section{MATERIAL AND METHODS}

\section{Design and Participants}

The study was conducted using a diagnostic survey method and survey technique. The subject of this study consisted of women who applied to two gynecology outpatient clinics in south-eastern Poland. The sample size required for a reliable factor analysis during the adaptation of a scale to a different culture, is classified as follows: 100 "poor", 200 "medium", 300"good", 500"very good", and 1000"perfect"[10, 11]. Based on this classification, it was aimed to reach 500 women, 443 of whom agreed to participate and were included in the study. Women meeting the inclusion criteria were selected from the relevant population by random sampling method. Inclusion criteria: sexually active women in aged over 18 years no communication problems and voluntary consent to participate in the study. The method of sample selection and data collection as well as the sample size were agreed with the author of the original version.

\section{Gynecological Cancers Awareness Scale (GCAS)}

GCAS was developed by Alp Dal and Ertem in 2017 to assess women's awareness of gynecological cancers and it is addressed to women aged 18-65 [12]. Given the cultural differences, the Polish version of the scale is addressed to sexually active adult women.

This GCAS scale consists of 41 statements divided on four subscales:

1. Awareness of Early Diagnosis and Knowledge of Gynecologic Cancers - items 1, 2, 12, 13;

2. Awareness of Gynecologic Cancer Risks - items 3-11;

3. Awareness of Gynecologic Cancer Prevention - items 14-19;

4. Awareness of Regular Control and Severe Disease Perception on Gynecologic Cancers - items 20-41.

It is a five-point Likert-type scale ( 1 = strongly disagree, $2=$ disagree, 3 = neither agree not to disagree, $4=$ agree, and $5=$ strongly agree). GCAS is evaluated against the overall result. The minimum score is 41 and the maximum score is 205. The higher the score, the higher the awareness of women. On the end of questionnaire, respondents were asked about socio-demographic data including age, place of residence and the level of education.

\section{Tool translation procedure}

The GCAS was translated into Polish by two independent translators, they then compared the two versions and created a single version of the translation. The English version has been retranslated into English by another translator. The main purpose of this process was preparation of a Polish version of the scale ready for practical use [13-15].

\section{Ethical consideration}

Prior to the study, permission was obtained to conduct the study from the researchers who developed the scale. The research tool was used with the authors' consent and prepared according to the rules adopted for the language adaptation process. Ethical approval (Decision No: 7/06/2021) was received from the Bioethics Committee at the University of Rzeszow Poland. Informed consent was obtained from the women included in the study.

\section{Pilot study}

The pilot study was carried out with 35 women to ensure that the prepared version of the tool was understandable. The data obtained from this pilot study was not included in the main sample. The pilot application determined that there were no misunderstood questions, and the Polish form of the scale was applied to the participants.

\section{Data collection}

The data was collected from June $10^{\text {th }}$ to July $10^{\text {th }}$ 2021 by midwives among women who applied to the gynecology polyclinics in Rzeszow for a routine check-up, and who agreed to participate in the study. The interviews were conducted on weekdays using an anonymous questionnaire and took approximately 10 minutes to complete.

\section{Psychometric analysis of the scale Validity analysis}

The adequacy and size of the sample were tested before factor analysis for the construct validity of the scale was done. Kaiser-Meyer-Olkin (KMO) test was used to determine the adequacy of the sample. Bartlett's Test of Sphericity analysis was conducted to determine whether the scale is suitable for factor analysis. KMO values used to decide whether the data is suitable for factor analysis or not are interpreted as follows; $0.90-1.00$ "perfect", 0.80 -0.89 "very good", 0.70-0.79 "good", 0.60-0.69 "medium", and $0.50-0.59$ "poor". The desired KMO value to conduct factor analysis should be over 0.60 [16].

Principal Component Analysis was used to examine the factor structure of the GCAS, and the results were evaluated according to the opinion that the factor loads of the questions obtained as result of the analysis should be at least 0.30 [17]. Confirmatory Factor Analysis (CFA) was applied to support the accuracy of the results obtained by explanatory factor analysis (EFA). As a result of CFA, the lower limits of the data fit index of the model were accepted as $\leq 5$ for $X^{2} / s d, \leq 0.08$ for RMSEA, and a value higher than 0.90 for GFI, CFI, and IFI [18]. 
Table 1. Statistical tests used in data analysis

\begin{tabular}{|l|l|}
\hline Test Used & Technique \\
\hline Content Validity & Davis Technique \\
\hline $\begin{array}{l}\text { Explanatory Factor } \\
\text { Analysis }\end{array}$ & $\begin{array}{l}\text { KMO and Bartlett Coefficients, Principal } \\
\text { Components Analysis }\end{array}$ \\
\hline $\begin{array}{l}\text { Explanatory Factor } \\
\text { Analysis }\end{array}$ & $\begin{array}{l}x^{2} / \text { SD value, GFI, AGFI, CFI, RMSEA, SRMR } \\
\text { fit indices, and PATH diagram }\end{array}$ \\
\hline Internal Consistency & $\begin{array}{l}\text { Cronbach a coefficient, item total } \\
\text { correlation, bottom top 27\% slice } \\
\text { comparison }\end{array}$ \\
\hline
\end{tabular}

\section{Reliability analysis}

The reliability value of the GCAS was determined through the Cronbach Alpha (a) coefficient. The Cronbach a reliability coefficients range from 0 to 1 . As the value approaches 1 , the reliability of the internal consistency of the scale increases. According to this, a value below 0.50 is unacceptable, values between $0.50-0.60$ are weak, values between $0.60-0.70$ are questionable, values between 0.70 0.80 are acceptable, values between $0.80-0.90$ are good, and values between $0.90-1.00$ are perfect [19].

The item-total correlation coefficients were examined to determine the relationship between the scores obtained from the scale items and the total score of the GCAS. The correlation values calculated between the items were above 0.20 , which was accepted as a sufficient value for the reliability of the scale [20].

\section{Data evaluation}

The data was analyzed with SPSS for Windows 22 package program and LISREL 8.80 package program. Numbers, percentages, minimum and maximum values, mean, and standard deviations as well as statistical analyzes stated in the Table 1 below were used in the analysis of the data.

\section{RESULTS}

There were 443 women in the study. A majority the respondents had secondary $(48.3 \%)$ or higher $(34.1 \%)$ education level. Residents of villages constituted $55.1 \%$ of the respondents, while $44.9 \%$ were from the city. The participants mean age was $33.64 \pm 11.19$ years, and their age differed from 18 to 65 years. The scale was examined in three different categories: content validity, construct validity, and internal validity, to determine whether the GCAS is valid and reliable in the Polish language.

\section{Findings regarding content validity}

The GCAS, whose validity and reliability were examined after the translation process was completed, was submitted to the opinion of 10 experts for evaluation regarding cultural equivalence to ensure content validity. The CVI scores of the items of the GCAS, whose content validity was evaluated using the Davis technique in the presence of expert opinions, are shown in Table 2.

CVI scores of all items belonging to the GCAS vary from 0.90 to 1.0. Therefore, no item was excluded from the scale in terms of content/scope validity (Tab. 2).

\section{Findings regarding construct validity}

After content validity, factor analysis was performed to determine the construct validity of the GCAS to obtain clearer findings in the study. KMO and Bartlett's tests were applied before factor analysis to evaluate the adequacy of the sample and the suitability of the data for factor analysis.

As shown in Table 3, the KMO value was determined as 0.896 , and this value shows suitability for principal components analysis. Similarly, the Bartlett test results $\left(x^{2}=83922.644, p=0.000\right)$ showed that the data correlate with each other and are suitable for factor analysis. In addition, the anti-image correlations of the scale items were also examined to evaluate whether the study data is suitable for factor analysis (Tab. 4). As seen in the table, all items meet the sampling adequacy criterion.

The items, factor loading and explained variance of the GCAS are shown in Table 5.

Routine Control and Serious Disease Perception in Gynecological Cancers Subdimension

1. Gynecological Cancer Risks Awareness Subdimension;

2. Protection from Gynecological Cancers Awareness Subdimension.

Early Diagnosis and Information Awareness in Gynecological Cancers Subdimension

Table 5 shows that the GCAS consists of four subdimensions, which is similar to the original structure. The factor loads of all the items of the scale are above 0.40 and the variance explained is $20.411 \%$ for Routine Control and Serious Disease Perception in Gynecological Cancers Subdimension, 9.185\% for Gynecological Cancer Risks Awareness Subdimension, 8.101\% for Protection from Gynecological Cancers Awareness Subdimension, 7.550\% for Early Diagnosis and Information Awareness in Gynecological Cancers Subdimension, and $45.247 \%$ for the Total Gynecological Cancers Awareness Scale. Therefore, no item was removed from the scale at this stage and the four subdimensions were accepted. Structural equation modeling was established with confirmatory factor analysis after explanatory factor analysis to obtain more precise findings.

\section{Findings regarding confirmatory factor analysis}

the fit index values found for the GCAS, and normal and acceptable values are shown in Table 6.

As seen in Table 6, many indexes were used to examine the fit of the model of the Gynecological Cancers Awareness 
Table 2. CVI Scores of GCAS Items

\begin{tabular}{|c|c|c|c|c|c|c|}
\hline \multicolumn{2}{|c|}{ Items } & \multirow{2}{*}{$\begin{array}{l}4 \\
9\end{array}$} & \multirow[t]{2}{*}{3} & \multirow{2}{*}{$\begin{array}{l}2 \\
-\end{array}$} & \multirow{2}{*}{$\begin{array}{l}1 \\
-\end{array}$} & \multirow{2}{*}{$\begin{array}{l}\text { CVIScore } \\
1.00\end{array}$} \\
\hline 1 & Ovarian cancer is a female genital organ cancer & & & & & \\
\hline 2 & Uterine cancer is a female genital organ cancer & 10 & - & - & - & 1.00 \\
\hline 3 & Not giving birth increases the risk of ovarian cancer & 10 & - & - & - & 1.00 \\
\hline 4 & $\begin{array}{l}\text { Menstruating at a young age (before the age of 9) and going through menopause at } \\
\text { an older age (after the age of 52) increases the risk of ovarian and uterine cancers }\end{array}$ & 7 & 3 & - & - & 1.00 \\
\hline 5 & The drugs used in the in-vitro fertilization treatment increase the risk of ovarian cancer & 10 & - & - & - & 1.00 \\
\hline 6 & $\begin{array}{l}\text { Receiving hormone therapy after menopause increases the risk of ovarian and uterine } \\
\text { cancers }\end{array}$ & 8 & 2 & - & - & 1.00 \\
\hline 7 & Being overweight increases the risk of ovarian and uterine cancers & 10 & - & - & - & 1.00 \\
\hline 8 & Being over the age of 50 increases the risk of uterine cancer & 10 & - & - & - & 1.00 \\
\hline 9 & Diabetes mellitus increases the risk of uterine cancer & 10 & - & - & - & 1.00 \\
\hline 10 & Not giving birth increases the risk of uterine cancer. & 10 & - & - & - & 1.00 \\
\hline 11 & Using contraceptive pills increase the risk of uterine and cervical cancers & 10 & - & - & - & 1.00 \\
\hline 12 & Early diagnosis is important in the female genital organ cancer & 10 & - & - & - & 1.00 \\
\hline 13 & $\begin{array}{l}\text { Having HPV (the virus causing cervical cancer) test is important for early diagnoses of } \\
\text { cervical cancer }\end{array}$ & 10 & - & - & - & 1.00 \\
\hline 14 & For the early diagnosis of cervical cancer, I have a cervical swab test performed & 10 & - & - & - & 1.00 \\
\hline 15 & $\begin{array}{l}\text { For the early diagnosis of the female external genital organ, I make self-examination } \\
\text { for the external genital organ }\end{array}$ & 7 & 3 & - & - & 1.00 \\
\hline 16 & I do not smoke in order to reduce the risk of female genital organ cancer & 10 & - & - & - & 1.00 \\
\hline 17 & $\begin{array}{l}\text { In order to reduce the risk of female genital organ cancer, I do not use contraceptive } \\
\text { pills for a long period }\end{array}$ & 8 & 2 & - & - & 1.00 \\
\hline 18 & I keep away from stress in order to reduce the risk of female genital organ cancer & 8 & 1 & 1 & - & 0.90 \\
\hline 19 & I regularly get examined by a gynecologist & 10 & - & - & - & 1.00 \\
\hline 20 & If I have pain in my abdomen, I go to a gynecologist & 10 & - & - & - & 1.00 \\
\hline 21 & Abdominal distention may be a serious symptom & 10 & - & - & - & 1.00 \\
\hline 22 & Abnormal vaginal bleeding may be a serious symptom & 10 & - & - & - & 1.00 \\
\hline 23 & Bleeding after sexual intercourse may be a serious symptom & 10 & - & - & - & 1.00 \\
\hline 24 & Too much menstrual bleeding may be a serious symptom & 10 & - & - & - & 1.00 \\
\hline 25 & Weight loss may be a serious symptom & 10 & - & - & - & 1.00 \\
\hline 26 & A palpable mass in the genital area may be a serious symptom & 10 & - & - & - & 1.00 \\
\hline 27 & A wound in the genital area may be a serious symptom & 10 & - & - & - & 1.00 \\
\hline 28 & Bleeding between menstruation periods may be a serious symptom & 10 & - & - & & 1.00 \\
\hline 29 & I go to a doctor if I have a sudden and irregular weight loss & 10 & - & - & - & 1.00 \\
\hline 30 & If I have a long-term diarrhea without a reason, I go to a doctor & 10 & - & - & - & 1.00 \\
\hline 31 & If there are people with ovarian cancer in my family, I go to a gynecologist & 10 & - & - & - & 1.00 \\
\hline 32 & If I have bleeding between menstruation periods, I go to a gynecologist & 10 & - & - & - & 1.00 \\
\hline 33 & If I have brown discharge, I go to a gynecologist & 10 & - & - & - & 1.00 \\
\hline 34 & If I have back pain, I go to a doctor & 10 & - & - & - & 1.00 \\
\hline 35 & If I have problem with urination, I go to a doctor & 10 & - & - & - & 1.00 \\
\hline 36 & If I have pain during sexual intercourse, I go to a gynecologist & 10 & - & - & - & 1.00 \\
\hline 37 & If I have continuous discharge, I go to a gynecologist & 10 & - & - & - & 1.00 \\
\hline 38 & If I have a problematic itch in my genital area, I go to a gynecologist & 10 & - & - & - & 1.00 \\
\hline 39 & If I have pain in my genital area, I go to a gynecologist & 10 & - & - & - & 1.00 \\
\hline 40 & If I have burning in my genital area, I go to a gynecologist & 10 & - & - & - & 1.00 \\
\hline 41 & If I have watery bloody discharge, I go to a gynecologist & 10 & - & - & - & 1.00 \\
\hline \multicolumn{2}{|c|}{ CVI mean } & \multicolumn{5}{|l|}{0.99} \\
\hline
\end{tabular}


Table 3. KMO and Bartlett test values for scale items

\begin{tabular}{l|l}
\hline KMO & 0.896 \\
\hline Bartlett & $x^{2}=8322.644, p=0.000$
\end{tabular}

\begin{tabular}{|c|c|c|c|c|c|c|c|c|c|c|c|c|c|c|c|c|}
\hline & S20 & S21 & S22 & S23 & S24 & S25 & S27 & S28 & S29 & S30 & S31 & S32 & S33 & S34 & S35 & S36 \\
\hline S20 & $0.920^{\mathrm{a}}$ & & & & & & & & & & & & & & & \\
\hline S21 & -0.224 & $0.932^{\mathrm{a}}$ & & & & & & & & & & & & & & \\
\hline S22 & -0.092 & -0.028 & $0.954^{a}$ & & & & & & & & & & & & & \\
\hline S23 & -0.028 & 0.033 & -0.219 & $0.930^{\mathrm{a}}$ & & & & & & & & & & & & \\
\hline S24 & 0.007 & -0.174 & -0.040 & -0.212 & $0.923^{\mathrm{a}}$ & & & & & & & & & & & \\
\hline S25 & 0.032 & -0.114 & -0.063 & -0.164 & -0.301 & $0.914^{\mathrm{a}}$ & & & & & & & & & & \\
\hline S27 & 0.042 & 0.026 & -0.027 & -0.051 & -0.073 & -0.139 & $0.922^{\mathrm{a}}$ & & & & & & & & & \\
\hline S28 & 0.056 & -0.073 & 0.022 & -0.099 & 0.075 & -0.003 & -0.263 & $0.928^{\mathrm{a}}$ & & & & & & & & \\
\hline S29 & 0.039 & -0.057 & 0.065 & -0.012 & -0.002 & -0.072 & 0.024 & -0.063 & $0.938^{a}$ & & & & & & & \\
\hline S30 & -0.231 & -0.121 & 0.069 & 0.075 & -0.162 & 0.060 & -0.086 & -0.027 & -0.150 & $0.882^{a}$ & & & & & & \\
\hline S31 & 0.007 & 0.076 & -0.010 & 0.052 & 0.069 & -0.049 & 0.011 & -0.045 & 0.004 & -0.179 & $0.930^{\mathrm{a}}$ & & & & & \\
\hline S32 & -0.008 & 0.042 & -0.106 & -0.022 & 0.003 & -0.114 & 0.042 & -0.182 & -0.089 & -0.004 & -0.230 & $0.930^{\mathrm{a}}$ & & & & \\
\hline S33 & -0.092 & 0.028 & -0.001 & 0.038 & -0.013 & 0.009 & 0.070 & -0.100 & -0.054 & 0.028 & 0.063 & -0.305 & $0.926^{\mathrm{a}}$ & & & \\
\hline S34 & -0.054 & -0.170 & 0.068 & -0.068 & 0.011 & -0.029 & -0.044 & -0.006 & -0.227 & -0.060 & -0.036 & 0.045 & -0.078 & $0.909^{a}$ & & \\
\hline S35 & -0.005 & 0.000 & -0.060 & 0.075 & -0.081 & 0.053 & 0.030 & 0.000 & -0.054 & 0.020 & -0.074 & -0.101 & -0.075 & -0.244 & $0.914^{\mathrm{a}}$ & \\
\hline S36 & 0.058 & -0.037 & -0.046 & -0.197 & 0.009 & 0.190 & -0.118 & 0.075 & -0.064 & 0.058 & -0.092 & 0.036 & -0.125 & -0.050 & -0.225 & $0.909^{\mathrm{a}}$ \\
\hline
\end{tabular}

\begin{tabular}{|c|c|c|c|c|c|c|c|c|c|c|c|c|c|c|c|c|c|}
\hline & S37 & S38 & S26 & S39 & S40 & S41 & S4 & S5 & S6 & S7 & S3 & S8 & S9 & S10 & S11 & S14 & S17 \\
\hline S37 & $0.908^{a}$ & & & & & & & & & & & & & & & & \\
\hline S38 & -0.186 & $0.920^{\mathrm{a}}$ & & & & & & & & & & & & & & & \\
\hline S26 & 0.085 & 0.019 & $0.939^{a}$ & & & & & & & & & & & & & & \\
\hline S39 & -0.002 & -0.394 & -0.292 & $0.931^{a}$ & & & & & & & & & & & & & \\
\hline S40 & -0.084 & -0.317 & -0.072 & -0.199 & $0.941^{a}$ & & & & & & & & & & & & \\
\hline S41 & -0.045 & 0.067 & -0.041 & -0.158 & -0.279 & $0.951^{\mathrm{a}}$ & & & & & & & & & & & \\
\hline S4 & -0.148 & 0.098 & 0.048 & -0.015 & 0.006 & -0.012 & $0.822^{\mathrm{a}}$ & & & & & & & & & & \\
\hline S5 & 0.020 & 0.087 & 0.008 & 0.014 & -0.028 & -0.022 & -0.213 & $0.857^{a}$ & & & & & & & & & \\
\hline S6 & -0.048 & -0.016 & 0.069 & 0.022 & -0.029 & 0.082 & 0.069 & -0.160 & $0.934^{a}$ & & & & & & & & \\
\hline S7 & -0.034 & 0.013 & -0.045 & -0.026 & 0.025 & -0.053 & -0.133 & 0.047 & -0.125 & $0.870^{\mathrm{a}}$ & & & & & & & \\
\hline S3 & 0.061 & -0.081 & -0.052 & 0.050 & 0.029 & 0.027 & -0.271 & -0.130 & -0.133 & -0.023 & $0.798^{\mathrm{a}}$ & & & & & & \\
\hline S8 & 0.077 & -0.068 & -0.027 & 0.004 & -0.036 & 0.043 & -0.104 & -0.015 & -0.050 & -0.208 & -0.004 & $0.903^{a}$ & & & & & \\
\hline S9 & 0.015 & 0.045 & -0.003 & 0.028 & -0.068 & -0.009 & 0.008 & 0.010 & -0.041 & -0.332 & -0.040 & -0.223 & $0.836^{\mathrm{a}}$ & & & & \\
\hline S10 & 0.028 & -0.132 & 0.012 & 0.024 & 0.036 & -0.075 & -0.126 & -0.071 & -0.012 & -0.100 & -0.470 & -0.004 & -0.026 & $0.817^{\mathrm{a}}$ & & & \\
\hline S11 & -0.092 & 0.037 & -0.052 & 0.052 & 0.055 & -0.025 & 0.012 & -0.109 & -0.123 & 0.040 & 0.038 & -0.032 & -0.134 & -0.154 & $0.814^{a}$ & & \\
\hline S14 & 0.045 & -0.014 & -0.002 & 0.047 & -0.007 & -0.016 & -0.023 & 0.010 & -0.051 & 0.094 & 0.046 & -0.097 & -0.139 & -0.005 & -0.018 & $0.891^{a}$ & \\
\hline S17 & 0.079 & -0.038 & 0.026 & 0.007 & 0.053 & -0.019 & -0.024 & -0.037 & -0.014 & -0.078 & -0.013 & -0.066 & 0.133 & 0.068 & -0.358 & -0.007 & $0.768^{\mathrm{a}}$ \\
\hline
\end{tabular}


Table 4. Anti-image correlations (continued)

\begin{tabular}{|l|l|l|l|l|l|l|l|l|} 
& $\mathbf{S 1 5}$ & $\mathbf{S 1 6}$ & $\mathbf{S 1 8}$ & $\mathbf{S 1 9}$ & $\mathbf{S 1}$ & $\mathbf{S 2}$ & $\mathbf{S 1 2}$ & $\mathbf{S 1 3}$ \\
\hline S15 & $0.895^{\mathrm{a}}$ & & & & & & \\
\hline S16 & -0.142 & $0.855^{\mathrm{a}}$ & & & & & \\
\hline S18 & -0.056 & -0.151 & $0.876^{\mathrm{a}}$ & & & \\
\hline S19 & -0.132 & -0.051 & -0.145 & $0.904^{\mathrm{a}}$ & & & \\
\hline S1 & 0.086 & -0.049 & 0.051 & 0.026 & $0.737^{\mathrm{a}}$ & & \\
\hline S2 & -0.064 & 0.013 & -0.095 & 0.043 & -0.777 & $0.730^{\mathrm{a}}$ & & \\
\hline S12 & 0.065 & -0.109 & -0.033 & -0.127 & 0.019 & -0.127 & $0.748^{\mathrm{a}}$ & \\
\hline S13 & -0.138 & -0.035 & 0.035 & 0.039 & -0.251 & 0.077 & -0.601 & $0.795^{\mathrm{a}}$ \\
\hline
\end{tabular}

aMeasures of Sampling Adequacy (MSA)

Table 5. Factor analysis findings for the GCAS

\begin{tabular}{|c|c|c|c|c|c|}
\hline \multirow{2}{*}{ Item no } & \multirow{2}{*}{ Items } & \multicolumn{4}{|c|}{ Factor/subdimension } \\
\hline & & 1 & 2 & 3 & 4 \\
\hline S20 & If I have pain in my abdomen, I go to a gynecologist & 0.520 & 0.158 & 0.185 & -0.054 \\
\hline S21 & Abdominal distention may be a serious symptom & 0.444 & 0.180 & 0.303 & -0.115 \\
\hline S22 & Abnormal vaginal bleeding may be a serious symptom & 0.601 & -0.081 & 0.406 & 0.132 \\
\hline S23 & Bleeding after sexual intercourse may be a serious symptom & 0.571 & 0.021 & 0.397 & 0.076 \\
\hline S24 & Too much menstrual bleeding may be a serious symptom & 0.507 & 0.075 & 0.336 & -0.039 \\
\hline S25 & Weight loss may be a serious symptom & 0.547 & 0.094 & 0.349 & 0.113 \\
\hline S26 & A palpable mass in the genital area may be a serious symptom & 0.659 & 0.004 & 0.315 & 0.183 \\
\hline S27 & A wound in the genital area may be a serious symptom & 0.509 & 0.147 & 0.240 & 0.184 \\
\hline S28 & Bleeding between menstruation periods may be a serious symptom & 0.438 & 0.133 & 0.278 & 0.173 \\
\hline S29 & I go to a doctor if I have a sudden and irregular weight loss & 0.535 & 0.296 & 0.077 & -0.084 \\
\hline S30 & If I have a long-term diarrhea without a reason, I go to a doctor & 0.489 & 0.263 & 0.042 & -0.164 \\
\hline S31 & If there are people with ovarian cancer in my family, I go to a gynecologist & 0.543 & 0.029 & 0.137 & 0.056 \\
\hline S32 & If I have bleeding between menstruation periods, I go to a gynecologist & 0.656 & -0.007 & 0.146 & 0.077 \\
\hline S33 & If I have brown discharge, I go to a gynecologist. & 0.666 & 0.036 & 0.043 & 0.027 \\
\hline S34 & If I have back pain, I go to a doctor & 0.524 & 0.175 & -0.010 & -0.090 \\
\hline S35 & If I have problem with urination, I go to a doctor & 0.652 & -0.047 & 0.003 & 0.000 \\
\hline S36 & If I have pain during sexual intercourse, I go to a gynecologist & 0.623 & -0.014 & 0.003 & 0.046 \\
\hline S37 & If I have continuous discharge, I apply to a gynecologist & 0.587 & 0.143 & -0.090 & -0.017 \\
\hline S38 & If I have a problematic itch in my genital area, I go to a gynecologist & 0.788 & -0.001 & 0.046 & 0.114 \\
\hline S39 & If I have pain in my genital area, I go to a gynecologist & 0.820 & -0.051 & 0.077 & 0.096 \\
\hline S40 & If I have burning in my genital area, I go to a gynecologist & 0.774 & -0.017 & 0.017 & 0.153 \\
\hline S41 & If I have watery bloody discharge, I go to a gynecologist & 0.692 & 0.022 & 0.047 & 0.182 \\
\hline S3 & Not giving birth increases the risk of ovarian cancer & 0.008 & 0.761 & 0.006 & 0.145 \\
\hline S4 & $\begin{array}{l}\text { Menstruating at an early age (before the age of } 9 \text { ) and going through menopause at a later } \\
\text { age (after the age of 52) increases the risk of ovarian and uterine cancers }\end{array}$ & 0.028 & 0.721 & -0.081 & 0.124 \\
\hline S5 & The drugs used in the in-vitro fertilization treatment increase the risk of ovarian cancer & 0.029 & 0.628 & 0.055 & -0.096 \\
\hline S6 & $\begin{array}{l}\text { Receiving hormone therapy after menopause increases the risk of ovarian and uterine } \\
\text { cancers }\end{array}$ & 0.211 & 0.539 & 0.223 & -0.014 \\
\hline S7 & Being overweight increases the risk of ovarian and uterine cancers & 0.065 & 0.541 & 0.281 & 0.239 \\
\hline S8 & Being over the age of 50 increases the risk of uterine cancer & 0.134 & 0.447 & 0.212 & 0.262 \\
\hline S9 & Diabetes mellitus increases the risk of uterine cancer & 0.056 & 0.485 & 0.288 & 0.107 \\
\hline S10 & Not giving birth increases the risk of uterine cancer & 0.032 & 0.735 & 0.082 & 0.033 \\
\hline
\end{tabular}


Table 5. Factor analysis findings for the GCAS (continued)

\begin{tabular}{|c|c|c|c|c|c|}
\hline \multirow{2}{*}{ Item no } & \multirow{2}{*}{ Items } & \multicolumn{4}{|c|}{ Factor/subdimension } \\
\hline & & 1 & 2 & 3 & 4 \\
\hline S11 & Using contraceptive pills increases the risk of uterine and cervical cancers & 0.039 & 0.449 & 0.372 & -0.023 \\
\hline S14 & For the early diagnosis of cervical cancer, I have a cervical swab test done & 0.124 & 0.089 & 0.521 & 0.306 \\
\hline S15 & $\begin{array}{l}\text { For the early diagnosis of the female external genital organ, I make self-examination for } \\
\text { the external genital organ }\end{array}$ & 0.162 & 0.180 & 0.482 & 0.159 \\
\hline S16 & I do not smoke in order to reduce the risk of female genital organ cancer & 0.022 & 0.036 & 0.664 & 0.221 \\
\hline S17 & $\begin{array}{l}\text { In order to reduce the risk of female genital organ cancer, I do not use contraceptive pills } \\
\text { for a long period }\end{array}$ & 0.019 & 0.226 & 0.628 & -0.072 \\
\hline S18 & I keep away from stress in order to reduce the risk of female genital organ cancer & 0.157 & 0.145 & 0.567 & -0.004 \\
\hline S19 & I regularly get examined by a gynecologist & 0.310 & 0.070 & 0.417 & 0.111 \\
\hline S1 & Ovarian cancer is a female genital organ cancer & 0.136 & 0.168 & 0.020 & 0.803 \\
\hline S2 & Uterine cancer is a female genital organ cancer & 0.117 & 0.165 & 0.030 & 0.762 \\
\hline S12 & Early diagnosis is important in the female genital organ cancer & -0.016 & -0.001 & 0.227 & 0.769 \\
\hline S13 & $\begin{array}{l}\text { Having HPV (the virus causing cervical cancer) test is important to early diagnose cervical } \\
\text { cancer }\end{array}$ & 0.066 & 0.065 & 0.197 & 0.791 \\
\hline \multicolumn{2}{|c|}{ Variance explained (\%) } & 20.411 & 9.185 & 8.101 & 7.550 \\
\hline \multicolumn{2}{|c|}{ Total variance explained (\%) } & \multicolumn{3}{|l|}{45.247} & \\
\hline
\end{tabular}

Table 6. Fit index values found for the Gynecological Cancers Awareness Scale, and normal and acceptable values

\begin{tabular}{|l|l|l|l|}
\hline Index & Normal value & Acceptable value & Found value \\
\hline$x^{2} / S D$ & $<2$ & $<5$ & 3.78 \\
\hline GFI & $>0.95$ & $>0.90$ & 0.94 \\
\hline AGFI & $>0.95$ & $>0.90$ & 0.93 \\
\hline CFI & $>0.95$ & $>0.90$ & 0.94 \\
\hline RMSEA & $<0.05$ & $<0.08$ & 0.056 \\
\hline SRMR & $<0.05$ & $<0.08$ & 0.071 \\
\hline
\end{tabular}

Scale. Of these, the $x^{2} / \mathrm{SD}$ value was found as $3.78, \mathrm{GFI}$ as 0.94, AGFI as 0.93, CFI as 0.94, RMSEA as 0.056, and SRMR as 0.071 . As a result of the relevant fit index values, it was decided that the model is acceptable in this state.

\section{Findings Regarding Internal Validity}

Table 7 presents item means, item total correlations, and Cronbach a coefficients if item is deleted from the GCAS.

As seen in Table 7, the Cronbach a coefficient is 0.943 for Total Gynecological Cancers Awareness Scale, 0.920 for Routine Control and Serious Disease Perception in Gynecological Cancers Subdimension, 0.814 for Gynecological Cancer Risks Awareness Subdimension, 0.719 for Protection from Gynecological Cancers Awareness Subdimension, and 0.849 for Early Diagnosis and Information Awareness in Gynecological Cancers Subdimension. Item-total correlations for all items of the scale are positive and the deletion of any item did not cause a significant increase in the Cronbach a coefficient of the scale. Therefore, no item was removed from the scale at this stage, either.
As seen in Table 8, the comparison results of the bottom and top $27 \%$ slice of the GCAS are statistically significant $(p<0.05)$. This result shows the discriminatory power of the scale.

The distribution of the min, max, and mean scores taken from the GCAS and its subdimensions is presented in Table 9 .

As seen in Table 9, the participants' mean scores were as follows: $84.27 \pm 12.02$ for Routine Control and Serious Disease Perception in Gynecological Cancers, $29.84 \pm 5.19$ for Gynecological Cancer Risks Awareness, $22.88 \pm 4.02$ for Protection from Gynecological Cancers Awareness, $17.80 \pm 2.94$ for Early Diagnosis and Information Awareness in Gynecological Cancers, and $154.79 \pm 17.85$ for the Total Gynecological Cancer Risks Awareness Scale.

\section{DISCUSSION}

It is very important to have knowledge about gynecological cancers. With increasing awareness of gynecological cancer, incidences can be reduced by enabling their prevention and early diagnosis [21]. For this purpose, valid 
Table 7. Item total correlations and Cronbach a coefficients of the Gynecological Cancers Awareness Scale

\begin{tabular}{|c|c|c|c|c|c|c|}
\hline no & Item & $\mathbf{n}$ & Mean & SD & $\begin{array}{l}\text { Item total } \\
\text { correlation }\end{array}$ & $\begin{array}{l}\text { Cronbach a } \\
\text { if an item is } \\
\text { deleted }\end{array}$ \\
\hline S20 & $\begin{array}{l}\text { If I have pain in my abdomen, } \\
\text { I go to a gynecologist }\end{array}$ & 443 & 30.37 & 10.152 & 0.488 & 0.911 \\
\hline S21 & Abdominal distention may be a serious symptom & 443 & 30.44 & 10.031 & 0.478 & 0.911 \\
\hline S22 & Abnormal vaginal bleeding may be a serious symptom & 443 & 40.16 & 0.878 & 0.579 & 0.910 \\
\hline S23 & Bleeding after sexual intercourse may be a serious symptom & 443 & 30.93 & 0.859 & 0.578 & 0.910 \\
\hline S24 & Too much menstrual bleeding may be a serious symptom & 443 & 30.81 & 0.946 & 0.499 & 0.911 \\
\hline S25 & Weight loss may be a serious symptom & 443 & 30.94 & 0.901 & 0.576 & 0.910 \\
\hline S26 & A palpable mass in the genital area may be a serious symptom & 443 & 40.15 & 0.805 & 0.624 & 0.909 \\
\hline S27 & A wound in the genital area may be a serious symptom & 443 & 30.88 & 0.871 & 0.542 & 0.910 \\
\hline S28 & Bleeding between menstruation periods may be a serious symptom & 443 & 40.13 & 0.715 & 0.506 & 0.911 \\
\hline S29 & I go to a doctor if I have a sudden and irregular weight loss & 443 & 30.34 & 10.037 & 0.499 & 0.911 \\
\hline S30 & If I have a long-term diarrhea without a reason, I go to a doctor & 443 & 30.13 & 10.184 & 0.415 & 0.912 \\
\hline S31 & If there are people with ovarian cancer in my family, I go to a gynecologist & 443 & 40.06 & 0.828 & 0.457 & 0.911 \\
\hline S32 & If I have bleeding between menstruation periods, I go to a gynecologist & 443 & 40.07 & 0.818 & 0.528 & 0.910 \\
\hline S33 & If I have brown discharge, like broth, I go to a gynecologist & 443 & 30.93 & 0.913 & 0.502 & 0.911 \\
\hline S34 & If I have back pain, I go to a doctor & 443 & 30.16 & 10.060 & 0.408 & 0.912 \\
\hline S35 & If I have problem with urination, I go to a doctor & 443 & 30.88 & 0.818 & 0.439 & 0.911 \\
\hline S36 & If I have pain during sexual intercourse, I go to a gynecologist & 443 & 30.86 & 0.803 & 0.440 & 0.911 \\
\hline S37 & If I have continuous discharge, I go to a gynecologist & 443 & 30.82 & 0.872 & 0.418 & 0.912 \\
\hline S38 & If I have a problematic itch in my genital area, I go to a gynecologist & 443 & 40.03 & 0.755 & 0.591 & 0.910 \\
\hline S39 & If I have pain in my genital area, I go to a gynecologist & 443 & 40.03 & 0.730 & 0.601 & 0.910 \\
\hline S40 & If I have burning in my genital area, I apply to a gynecologist & 443 & 40.01 & 0.757 & 0.570 & 0.910 \\
\hline S41 & If I have watery bloody discharge, I go to a gynecologist & 443 & 40.14 & 0.728 & 0.549 & 0.910 \\
\hline S3 & Not giving birth increases the risk of ovarian cancer & 443 & 30.16 & 10.042 & 0.313 & 0.913 \\
\hline S4 & $\begin{array}{l}\text { Menstruating at an early age (before the age of 9) and going through } \\
\text { menopause at a later age (after the age of 52) increases the risk of } \\
\text { ovarian and uterine cancers }\end{array}$ & 443 & 30.35 & 0.906 & 0.276 & 0.913 \\
\hline S5 & $\begin{array}{l}\text { The drugs used in the in-vitro fertilization treatment increase the risk of } \\
\text { ovarian cancer }\end{array}$ & 443 & 30.14 & 0.827 & 0.242 & 0.913 \\
\hline S6 & $\begin{array}{l}\text { Receiving hormone therapy after menopause increases the risk of } \\
\text { ovarian and uterine cancers }\end{array}$ & 443 & 30.23 & 0.738 & 0.438 & 0.911 \\
\hline S7 & Being overweight increases the risk of ovarian and uterine cancers & 443 & 30.44 & 0.974 & 0.410 & 0.912 \\
\hline S8 & Being over the age of 50 increases the risk of uterine cancer & 443 & 30.66 & 0.856 & 0.404 & 0.912 \\
\hline S9 & Diabetes mellitus increases the risk of uterine cancer & 443 & 30.26 & 0.862 & 0.352 & 0.912 \\
\hline S10 & Not giving birth increases the risk of uterine cancer & 443 & 30.13 & 0.957 & 0.323 & 0.913 \\
\hline S11 & Using contraceptive pills increases the risk of uterine and cervical cancers & 443 & 30.47 & 0.996 & 0.338 & 0.913 \\
\hline S14 & For the early diagnosis of cervical cancer, I have a cervical swab test done & 443 & 40.15 & 0.907 & 0.402 & 0.912 \\
\hline S15 & $\begin{array}{l}\text { For the early diagnosis of the female external genital organ, I make self- } \\
\text { examination for the external genital organ }\end{array}$ & 443 & 30.90 & 0.967 & 0.421 & 0.912 \\
\hline S16 & I do not smoke in order to reduce the risk of female genital organ cancer & 443 & 30.98 & 10.070 & 0.353 & 0.913 \\
\hline S17 & $\begin{array}{l}\text { In order to reduce the risk of female genital organ cancer, I do not use } \\
\text { contraceptive pills for a long period }\end{array}$ & 443 & 30.57 & 10.083 & 0.333 & 0.913 \\
\hline S18 & $\begin{array}{l}\text { I keep away from stress in order to reduce the risk of female genital } \\
\text { organ cancer }\end{array}$ & 443 & 30.32 & 10.082 & 0.401 & 0.912 \\
\hline S19 & I regularly get examined by a gynecologist & 443 & 30.96 & 10.113 & 0.444 & 0.911 \\
\hline S1 & Ovarian cancer is a female genital organ cancer & 443 & 40.47 & 0.854 & 0.369 & 0.912 \\
\hline
\end{tabular}


Table 7. Item total correlations and Cronbach a coefficients of the Gynecological Cancers Awareness Scale (continued)

\begin{tabular}{|c|c|c|c|c|c|c|}
\hline no & Item & n & Mean & SD & $\begin{array}{l}\text { Item total } \\
\text { correlation }\end{array}$ & $\begin{array}{l}\text { Cronbach a } \\
\text { if an item is } \\
\text { deleted }\end{array}$ \\
\hline S2 & Uterine cancer is a female genital organ cancer & 443 & 40.47 & 0.843 & 0.348 & 0.912 \\
\hline S12 & Early diagnosis is important in the female genital organ cancer & 443 & 40.51 & 0.913 & 0.269 & 0.913 \\
\hline S13 & $\begin{array}{l}\text { Having HPV (the virus causing cervical cancer) test is important to early } \\
\text { diagnose cervical cancer }\end{array}$ & 443 & 40.35 & 0.933 & 0.349 & 0.912 \\
\hline \multicolumn{5}{|c|}{ Routine Control and Serious Disease Perception in Gynecological Cancers Cronbach a } & \multicolumn{2}{|l|}{0.920} \\
\hline \multicolumn{5}{|c|}{ Gynecological Cancer Risks Awareness Cronbach a } & \multicolumn{2}{|l|}{0.814} \\
\hline \multicolumn{5}{|c|}{ Protection from Gynecological Cancers Awareness Cronbach a } & \multicolumn{2}{|l|}{0.719} \\
\hline \multicolumn{5}{|c|}{ Early Diagnosis and Information Awareness in Gynecological Cancers Cronbach a } & \multicolumn{2}{|l|}{0.849} \\
\hline \multicolumn{5}{|c|}{ Total Gynecological Cancers Awareness Cronbach a } & \multicolumn{2}{|l|}{0.913} \\
\hline
\end{tabular}

\begin{tabular}{l|l|l|l|l|}
\hline Table 8. Bottom top 27\% slice comparison results \\
\hline & $\mathbf{n}$ & Mean & SD & Significance \\
\hline Bottom 27\% & 120 & 133.73 & 12.16 & $\mathrm{t}=-31.130$ \\
\hline Top 27\% & 120 & 176.05 & 8.59 & $\mathrm{p}=\mathbf{0 . 0 0 0}$ \\
\hline
\end{tabular}

\begin{tabular}{|l|l|l|l|l|l|}
\hline Table 9. Distribution of scores obtained from Gynecological Cancers Awareness Scale and subdimensions \\
\hline Subscales & n & Min. & Max. & Mean & SD \\
\hline Routine Control and Serious Disease Perception in Gynecological Cancers & 443 & 24.00 & 110.00 & 84.27 & 12.02 \\
\hline Gynecological Cancer Risks Awareness & 443 & 16.00 & 45.00 & 29.84 & 5.19 \\
\hline Protection from Gynecological Cancers Awareness & 443 & 6.00 & 30.00 & 22.88 & 4.02 \\
\hline Early Diagnosis and Information Awareness in Gynecological Cancers & 443 & 4.00 & 20.00 & 17.80 & 2.94 \\
\hline Total Gynecological Cancers Awareness & 443 & 72.00 & 203.00 & 154.79 & 17.85 \\
\hline
\end{tabular}

and reliable measurement tools are needed to determine gynecological cancer awareness. This section discusses the findings obtained from the research conducted to ensure the validity and reliability of the GCAS under the following headings:

Validity is the degree to which a measurement tool can measure the property that it aims to measure accurately without reflecting the effect of any other feature on the measurement. $[22,23]$. To test the validity of the GCAS, it was first adapted to Polish. Language validity, content validity, and a pilot application were carried out in this regard. In the adaptation phase of the GCAS to the Polish culture, it was first translated from its original language Turkish into English and then from English into Polish. Then, the scale items, which were translated into Polish, were examined by expert linguists, and the original scale was compared to the Polish translation. The Polish form of the scale was presented to 10 academicians who are experts in their fields to evaluate the content validity.

After language validity, content validity, and pilot application, the study proceeded with the construct validity.
Construct validity is performed to evaluate how accurately an abstract concept or behavior can be measured by the tool $[23,24]$. Factor analysis method, one of the most frequently used methods, was used to ensure construct validity. Prior to factor analysis, KMO analysis was performed to test the sample size sufficiency and appropriateness. The KMO value of the GCAS was determined as 0.896 (Tab. 3). The KMO value of the Turkish version of the Scale was found as 0.943 [12]. The sample size analysis value $x^{2}=8322.644, p=0.000$ tested in the study showed that the sample size was quite sufficient and suitable for factor analysis (Tab. 3).

Varimax rotation was used in the EFA stage of factor analysis. The variance explained for the scale was found as $45.24 \%$ (Tab. 5). As a result, it was determined that the variance explained according to the EFA findings was at a satisfactory level. The original GCAS consists of 41 items. In the literature, the lower value for the factor loading of the items in the measurement tool was specified as $0.30-0.40$. As a result of EFA in this study, it was determined that the Gynecological Cancers Awareness Scale was gathered under 
four factors as in the original. As a result, the Polish version of the Gynecological Cancers Awareness Scale consisting of 41 items was obtained (Tab. 5).

According to the CFA results, the $x^{2} / \mathrm{SD}$ value was found as 3.78, GFI as 0.94, AGFI as 0.93, CFI as 0.94, RMSEA as 0.056, and SRMR as 0.071 (Tab. 6). According to the relevant fit index values, it was decided that the model was acceptable in this state.

Reliability shows the invariance of the measurement tool, consistency, the ability to reach similar results in measurements made at different times and is used to determine the true value levels. If the reliability of a measurement tool is found to be low, its scientific value is also considered low [25]. Cronbach's alpha internal consistency coefficient and item total correlation were used to determine the reliability of the Polish version of the GCAS.

In this study, the Cronbach's alpha internal consistency coefficient of the GCAS was found to be 0.913 (Tab. 7). The Cronbach's alpha internal consistency coefficient of the original scale was 0.944 [12].

\section{CONCLUSIONS}

Since the Gynecological Cancer Awareness Scale, which was developed by Alp Dal and Ertem (2017) to measure the Gynecological Cancer Awareness of women and which we have made valid and reliable in Polish, is harmonious with the original scale, it was determined that it is a valid and reliable tool for evaluating the gynecological cancer awareness of Polish women.

\section{Acknowledgements}

Authors would like to thank all the women who voluntary participated at the study.

\section{Funding}

Research was partially supported by the statutory fund of the Medical College of Rzeszow University.

\section{Conflict of interest}

All authors declare no conflict of interest.

\section{REFERENCES}

1. Wojciechowska U, Didkowska J. Zachorowania i zgony na nowotwory złośliwe w Polsce. Krajowy Rejestr Nowotworów, Narodowy Instytut Onkologii im. Marii Skłodowskiej-Curie - Państwowy Instytut Badawczy. http://onkologia.org.pl/raporty/ (10.06.2021).

2. Wojciechowska U, Didkowska J, et al. Nowotwory złośliwe w Polsce w 2018 roku. Narodowy Instytut Onkologii im. Marii Skłodowskiej-Curie - Państwowy Instytut Badawczy. Warszawa, 2020.
3. Lopez MS, Baker ES, Maza M, et al. Cervical cancer prevention and treatment in Latin America. J Surg Oncol. 2017; 115(5): 615-618, doi: 10.1002/jso.24544, indexed in Pubmed: 28168717.

4. Akita S, Mitsukawa N, Rikihisa N, et al. Early diagnosis and risk factors for lymphedema following lymph node dissection for gynecologic cancer. Plast Reconstr Surg. 2013; 131(2): 283-290, doi: 10.1097/PRS.0b013e318277870f, indexed in Pubmed: 23357989.

5. Kessler TA. Cervical cancer: prevention and early detection. Semin Onco Nurs. 2017; 33(2): 172-183, doi: 10.1016/j.soncn.2017.02.005, indexed in Pubmed: 28343836.

6. Evcili F, Bekar M. Prevention of gynecological cancers: the affecting factors and knowledge levels of Turkish women. Journal of Health Research. 2020; 34(5): 431-441, doi: 10.1108/jhr-07-2019-0171.

7. Linkov F, Goughnour SL, Adambekov S. Lifestyle interventions to reduce the risk of obesity-associated gynecologic malignancies: a focus on endometrial cancer. In: Berger NA, Klopp AH, Lu KH. ed. Focus on Gynecologic Malignancies. Springer, Cham 2018: 137-165.

8. Özcan H, Doğan MD. Gynecological cancer awareness among women. In dian J Gynecol Oncolog. 2021; 19(13), doi: 10.1007/s40944-020-00481-w.

9. Dursun P, Gültekin M, Taşkıran Ç. Güneş Tıp Kitabevleri. In: Ayhan A. ed. Jinekolojik onkoloji. 2013: 27-51.

10. Comrey A, Lee H. A first course in factor analysis. NJ Erlbaum, Hillsdale 1992: 49-52.

11. Pearson RH. Recommended sample size for conducting exploratory factor analysis on dichotomous data. University of Northern Colorado, 2008.

12. Dal NA, Ertem G. Gynecological cancer awareness scale development study. Journal Of The Human \& Social Science Researches. 2017; 6(5): 2351-2367.

13. Wild D, Grove A, Martin M, et al. ISPOR Task Force for Translation and Cultural Adaptation. Principles of good practice for the translation and cultural adaptation process for patient-reported outcomes (PRO) measures: report of the ISPOR Task Force for Translation and Cultural Adaptation. Value Health. 2005; 8(2): 94-104, doi: 10.1111/j.1524-4733 .2005.04054.x, indexed in Pubmed: 15804318.

14. Brzyski P. Aspekty metodologiczne użycia skal, jako instrumentów pomiarowych w badaniach epidemiologicznych. Przegląd Lekarski. 2012; 69(12): 1287-1292.

15. Drwal R. Problemy kulturowej adaptacji kwestionariuszy osobowości In: Ciechanowicz A. ed. Kulturowa adaptacja testów. Polskie Towarzystwo Psychologiczne, Wydział Psychologii Uniwersytetu Warszawskiego, Laboratorium Technik Diagnostycznych im. Bohdana Zawadzkiego, Warszawa 1990.

16. Alpar R. Uygulamalı İstatistik ve Geçerlik-Güvenirlik. Detay Yayıncılık, Ankara 2012: 496-506.

17. Büyüköztürk, Ş. Sosyal bilimler için veri analizi el kitabı: İstatistik, araştırma deseni, SPSS uygulamaları ve yorum. 2002.

18. Gürbüz B, Öncü E, Emir E. The Turkish adaptation of leisure facilitator scale: a validity and reliability study. Physical education of students. 2019; 23(2): 64-69, doi: 10.15561/20755279.2019.0202.

19. Gliem JA, Gliem RR. Calculating, interpreting, and reporting Cronbach's alpha reliability coefficient for Likert-type scales. Midwest Research to Practice Conference in Adult, Continuing, and Community Education. 2003: 82-88.

20. Briggs $S$, Cheek J. The role of factor analysis in the development and evaluation of personality scales. Journal of Personality. 1986; 54(1): 106-148, doi: 10.1111/j.1467-6494.1986.tb00391.x.

21. Fonnes T, Telle IO, Forsse D, et al. Cancer awareness in the general population varies with sex, age and media coverage: a population-based survey with focus on gynecologic cancers. Eur J Obstet Gynecol Reprod Biol. 2021; 256: 25-31, doi: 10.1016/j.ejogrb.2020.10.051, indexed in Pubmed: 33161211.

22. Büyüköztürk Ş, Çakmak EK, Akgün ÖE. Bilimsel araştırma yöntemleri. Pegem A Yayıncılık, Ankara 2016.

23. Karakoç A, Dönmez P. Ölçek Geliştirme Çalışmalarında Temel İlkeler. Tıp Eğitimi Dünyası. 2014; 13(40): 39-49, doi: 10.25282/ted.228738.

24. Ercan İ, Kan İ. Ölçeklerde güvenirlik ve geçerlik. Uludağ Üniversitesi Tıp Fakültesi Dergisi. 2004; 3: 211-216.

25. Bowling A, Ebrahim S. Handbook of health research methods: investigation, measurement and analysis. McGraw-Hill Education, London 2005. 